Volume 6, Issue 2 (2021), pp. 90-98

Journal of School Administration Research and Development ISSN: 2470-8496 Print/ ISSN: 2470-850X Online

ojed.org/jsard

\title{
Student Social Class Identity Development: A Perspective on Dual Credit Programming
}

\author{
Alexandrea Horton \\ Crown Point Community School Corporation, USA
}

\begin{abstract}
Student social class identity development is a relatively unexamined aspect of student identity development throughout adolescents' educational experiences. Negative student social class identity development amongst low-social class adolescent students is increasing along with the growth of dual credit programs. This article will first discuss several negative and positive influences of dual credit programs on adolescent students' social class identity development. Suggestions of specific dual credit program procedures that may help encourage a more positive social class identity development amongst low-social class students will follow.
\end{abstract}

Keywords: social class, student identity development, dual credit

Student identity development is a relatively unexamined aspect of student development throughout an individual's educational experiences. Unique to a student's identity development is their social class history and the educational opportunities afforded to them during their secondary education experiences. The U.S. Department of Education and State Department of Education continue to reform and create new policies with an emphasis on postsecondary placement. Subsequently, this emphasis encourages the growth and integration of dual credit programming opportunities (Cram \& Bajar, 2019; Karp et al, 2004; Nelson \& Waltz, 2017). Socioeconomic status is often associated with social class. Socioeconomic status represents objective dimensions of those circumstances, whereas social class represents the experience of those shared economic circumstances in relation to positions of power (Padgett et al., 2010; Patton et al., 2016). Affordability becomes a major factor when assessing the impact that dual credit programs have on an adolescent's social class and identity development. However, as there is no nation-wide transparency with dual credit policies, there remains a significant and inequitable dual credit accessibility barrier for low-socioeconomic (low-SES) families. Thus, these barriers may result in identity development disparities amongst low-SES students throughout their education, prompting action in education policy and institutional procedure reform.

Nelson and Waltz (2017) explain that although college-readiness program terminology is found to be used interchangeably, there is a distinct difference between the programs. 'Dual credit' refers to programs where students receive both high school and college credit upon successful completion of the course (Capstick et al., 2019; Nelson \& Waltz, 2017). Social class can be defined as a large group of individuals who share similar economic and/or social positions in society based on their income, wealth, property ownership, job status, education, skills, or power in the economic and political realm in relation to those who have more and those who have less (Capstick et al., 2019; Ecute, 2019; Patton et al., 2016). One area of social class discrepancy that impacts college students' identity development is the inequitable educational opportunity to participate in dual credit programs as secondary education students.

Due to recent emphasis of education policy focus onto dual credit, dual credit courses are increasingly being adopted in secondary education institutions. The adoption of dual credit courses is helping make waves in overall student academic development and preparation for higher education. When adopting dual credit courses into secondary education institutions, it is important to assess the equitable educational opportunities of these programs in relation to their positive and/or negative influence. Dual credit course participation directly impacts high school and college students' social class 
identity development. Thus, it indirectly influences each students' success in their higher education academic achievements (Ecute, 2019; Padgett et al., 2010; Patton et al., 2016; Rubin et al., 2019; Veldman et al., 2019). It is through a deeper analysis of the education policies and institutional procedures, focused on dual credit programming, that school leaders and policy makers can advocate for policy and program reform. This will ultimately encourage more positive social class identity development amongst low-social class adolescent students applying for and enrolled in dual credit courses.

\section{STUDENT SOCIAL CLASS IDENTITY DEVELOPMENT}

If dual credit programs across the states remain predominantly available in higher socioeconomic regions and not in historically underprivileged regions, there is a greater perceived risk that college students will have developed a lesser sense of self and a lower social class identity. This lesser sense of self and having a lower social class identity can be discovered upon their entering as a freshman and even progressing throughout their first academic year on a college campus (Cram \& Bejar, 2019). Essentially, social class identity is centered on the income, wealth, status, and cultural capital of those with more, or less. An individual's social class identity directly influences how they feel about themselves in relation to others who have more, or less, economic privileges (Ecute, 2019; Harris \& Radunovich, 2019; Patton et al., 2016). This perceived risk is based on the research conducted on the inequitable access that low social class and socioeconomic secondary education students have to participate in and earn college credits through dual credit programs. This inequitable access to dual credit programs created a larger education equity gap between social classes in regard to college readiness and attainment (Burns et al, 2019; Veldman et al., 2019).

When students enter their first college year at a recognized disadvantage to their high social class and collegeprepared peers, they are more likely to feel like they do not belong and presumably acquire a discouraging sense of self. Students are likely to experience recognized disadvantages through systemic oppressions such as marginalization, cultural imperialism, and powerlessness (Garriott, 2019; Harris \& Radunovich, 2019). According to Patton et al. (2016), student development includes theories of social identities (e.g., race, ethnicity, sexual identity, gender, religion, ability, social class), psychosocial identity development, cognitive/epistemological development, moral development, and holistic selfauthorship. The categories are not mutually exclusive; they overlap in the lived experience of college students, as, for example, in the ways that increased complexity in ways of thinking (cognitive) leads to increased complexity in ways of understanding moral dilemmas. (p. 31)

Patton et al. (2016) explains how social class identity has a direct impact on and inherently shapes classroom discourse on a college campus, including the curriculum, course content, and pedagogical processes. For example, students with little to no access to dual credit programs are less inclined to contribute to the academic discourse of the class. This is due to the student having little to no experience in this format of conversation (Padgett et al., 2010). A lack of access to dual credit programs is typically due to its unaffordability based on a student's low socioeconomic background. Conversely, students who are from considerably more advantaged backgrounds may be naturally more willing to contribute to the academic discourse of the college class. This is often due to having had more opportunities to participate in a college setting through their involvement in dual credit classes while they were in high school. Higher social class and socioeconomic students are typically able to afford the registration and tuition costs of dual credit courses.

A students' social class identity can have an immediate impact on their college experiences. Students' low social class identity may not allow them to enroll in daytime courses because they may be required to go to work during those hours. The low social class identity college student may have limited course selections based on his or her work schedule. Often, a working-class student prioritizes work, thus basing their course options on their work schedule. This can impact which postsecondary institution a low social class identity college student can apply to (Garriott, 2019; Padgett et al., 2010; Rubin et al., 2019). If a student's low social class background still allows them to attend the traditional daytime courses, their particular social class background can serve as an opportunity for them to share their unique experiences. In addition, the student will have greater opportunities to explore the diverse and unique experiences of their middle to high social class peers (Padgett et al., 2010).

\section{DUAL CREDIT PROGRAM PROCEDURE DISCREPENCIES}

Nelson and Waltz (2017) further elaborate on the inconsistencies of dual credit programs. Various financial supports that low social class students have depending on the state in which they are a student are reviewed. Nelson and Waltz (2017) discuss how a majority of states provide potential cost defrayment for historically and contemporaneously marginalized and disenfranchised students. However, the potential of removing these financial barriers to underprivileged students is 
arguably a double-edged sword because these students are most often underaged and underdeveloped for exposure to such a rigorous college atmosphere (Nelson \& Waltz, 2017). Veldman et al. (2019) disagrees by arguing that the importance of social adjustment is a factor in lessening the social-class achievement gap. Lower social integration among students who experience low social class identity-compatibility is a contributor through which disparities in academic achievement between low social class and middle to high social class students commonly arise. Manstead (2018) found that, "relatively disadvantaged students (whose parents had low levels of educational attainment) scored lower on identity compatibility and that low scores on identity compatibility were associated with lower anticipated acceptance at prestigious universities" (p. 281).

From a financial standpoint, Karp et al. (2004) claim that discovering methods to cover the cost of student enrollment in dual credit programs avoids the barrier of low social class students not having the same educational opportunities of and access to programs that their middle and upper social class peers do. Karp et al. (2004) states that if students are expected to contribute financially, those from low-income families may be unable to participate in those additional educational opportunities. Various funding methods and strategies that have been applied by multiple states are laid out throughout the research of Karp et al. (2004), delivering examples of their application.

For most students, having the skills necessary is only a partial issue; but, not having enough money to pay for college is a primary issue. Gaps in wages perpetuate the cycle of low social class students and families having less representation in post-secondary institutions (Ecute, 2019). There are two priority decisions that states must make when deciding on the funding components of dual credit programs: who is going to pay the tuition and how state Average Daily Attendance (ADA) and Full Time Equivalent (FTE) funding streams will be directed (Karp et al., 2004). Karp et al. (2004) offers a simplistic overview of the complexities of ADA and FTE funding in regard to dual credit programs. ADA funding is described as addressing the costs of the dual credit program to the student, whereas FTE funding addresses the funding streams for secondary education and postsecondary institutions. The combination of ADA and FTE funding create an even more complicated and varied result (Karp et al., 2004). In one noted instance, Karp et al. (2004) mentions how if states find themselves under significant fiscal pressure, legislators and congressional leaders may choose to eliminate the dual credit programs altogether - to which Massachusetts served as a realistic case study. This issue of funding thus propagates the significant rate of first generation and low social class students - who are not college ready - dropping out after their first year of college (Ecute, 2019).

In respect to the funding procedures for implementation of dual credit courses, there continues to be major discrepancies across the states. One discrepancy example is establishing which party is responsible for making the tuition payment. These discrepancies may make it uniquely challenging to determine the true opportunities and/or barriers that dual credit programs inherently contribute to academic achievement and identity development of low social class students (Garriott, 2019; Harris \& Radunovich, 2019; Rubin et al., 2019). If students are expected to contribute financially to the dual credit course tuition, low income and social class families may be unable to partake in the dual credit program. This ultimately enlarges the inaccessibility to higher education opportunities (Karp et al., 2004). In contrast, states like Georgia, Indiana, Louisiana, and Missouri have enlisted and refined their education policies to ensure that dual credit courses are paid for either by the higher education institution, the secondary education institution, or have tuition waived completely (ECS, 2021). In some instances, both the higher education and secondary institutions are expected to pay for the dual credit course for each student. When both institutions are expected to pay for the dual credit course for each student, it is known as double dipping. Double dipping is when both institutions receive state funding per student, so the state pays twice (Karp et al., 2004). Double dipping can be viewed as institutionally beneficial, as it promotes student participation in dual credit programs. Although, other state constituents may contend this notion.

Despite these state-by-state differences, policymakers and practitioners are increasingly guiding secondary education students into enrolling in more dual credit programs across the nation (Burns et al., 2019; Cram \& Bejar, 2019; Nelson \& Waltz, 2017). An's (2012) research discovered that although these state discrepancies remain predominant, most state dual credit programs tend to focus on regions and school districts where students often graduate high school and move on to attend high tuition charging institutions such as private and/or public out-of-state colleges and universities. Nonetheless, if dual enrollment programs remain limited for reasons including funding, students who are members of historically and contemporaneously disenfranchised and marginalized groups still have the most to lose in regard to their pursuit of educational equity and postsecondary study access (Nelson \& Waltz, 2017, p.3). When assessing the value of dual credit programs on higher education access to historically marginalized student bodies, including, but not limited to, those from low social class and low socioeconomic backgrounds, in comparison to other advanced placement or collegereadiness programs, it can be observed that there is a greater constructive correlation (Ecute, 2019; Garriott, 2019). 


\section{LOW SOCIAL CLASS STUDENT DUAL CREDIT BARRIERS}

Patton et al. (2016) provide detailed research on the theory of student social identities: race, ethnicity, sexual identity, gender, religion, ability, and social class of college student development. College students are defined by Patton et al. (2016) as individuals engaged in postsecondary learning experiences, which is in alignment with students enrolled in dual credit courses. Patton et al. (2016) discussed how students from low social class backgrounds are assumed to bring values that differ and conflict with values within higher education. This offers a comparison of presumptions of such students to those of upper-class students. Pagett et al. (2010) claims that socioeconomic status in connection with a low social class identity is an important part of the socialization process for college students. Low social class students are often firstgeneration, poor, and working-class students - to which the poorest of most families are headed by single mothers (Patton et. al, 2016).

In respect to low social class students, affordability of college is displayed as a key indicator of whether or not a postsecondary education was even an option. In particular, working-class students' minority group status is more evident at university than in their prior K-12 education settings. This potentially leads to low social class students feeling out of place on campus (Rubin et al., 2019). Since low social class students are often the first generation to attend college in their families, their families may have less experience with colleges and are thus often unable to provide the same level of financial, informational, mentoring, and/or identity support that most middle to high social class families may provide for their children attending college (Rubin et al., 2019).

Moreover, Patton et al. (2016) continues by providing evidence of how a low social class student's educational experience on a college campus is starkly different from their middle- and upper-class peers. Low social class students spend less time participating in campus activities and clubs due to using this extra time to fulfill other obligations such as working or taking care of other means at home. Padgett et al. (2010) add that given the non-collegiate background of low social class and first-generation families, it is a high possibility that the college experience of interacting with faculty may be unnerving to these students. Thus, increasing the probability that they abandon the opportunities they do have to participate in these campus activities. Garriott (2019) claims that researchers have proven that experiences such as not being able to participate in student activities due to time or cost, inability to afford textbooks, and inability to take a class or switch majors due to financial constraints, are associated with first generation students' subjective social status, life satisfaction, and academic satisfaction. This alludes to the notion that higher education institutions actually create large gaps and barriers for low social class students to have to overcome. Patton et al. (2016) describes how these gaps, barriers, and overall discrepancies contribute to low social class students having feelings of exclusion and of being academically underprepared in comparison to their upper social class peers. Low social class students also often report lower subjective social status, feeling undervalued by their academic institutions, and tend to be the targets of negative comments from peers and faculty based on their low social class and inability to participate in campus activities (Garriott, 2019).

Moving forward from the concerns of Patton et al. (2016), Nelson and Waltz (2017) discuss the litigation and equity components of dual credit programs. Underlining the fact that state implementation of dual credit programs lacks complete consensus on students who can participate, Nelson and Waltz (2017) suggest divergent and disparate means in which dual enrollment programs are implemented. Garriott (2019) states that institution-sponsored student programming, that supports students both financially and socially, could decrease students' overall feelings of marginalization. Veldman et al. (2019) claim that students who experience low social class identity-compatibility feel less well prepared before starting at university. A way to alleviate student under preparedness would be to coach them in how to prepare for classes and exams, as well as where to find and how to access university and academic support services (Hanover Research, 2014).

Despite the disparities amongst state-wide dual credit program implementation methods, Nelson and Waltz (2017) have discovered that historically disadvantaged students classified as racial minorities, ethnic minorities, low socioeconomic status, low social class, and female typically have very positive outcomes upon their completion of such programs (p.8). 


\section{NEGATIVE LOW-SOCIAL CLASS IDENTITY DEVELOPMENT IN DUAL CREDIT STUDENTS}

Patton et al. (2016) adolescent students' social class identity development theory therefore becomes an integral component to understanding how those dual credit program procedures impact former and present dual credit students. More specifically, an aspect of student development that significantly impacts a college student's experience within higher education is social class (Padgett et al., 2010; Veldman et al., 2019). The choice an adolescent makes to enroll in dual credit courses, as well as his or her experience when doing so, is consequently and highly dependent on the program's affordability. Similarly, this pattern of decision making based on affordability can be observed when high school students are deciding to apply and register for college and which higher education institutions they apply to (Harris \& Radunovich, 2019; Padgett et al., 2010; Rubin et al., 2019). This emphasis on the affordability of higher education, as a dual credit program and/or as a separate education experience, proves that it considerably influences the social class and identity development of students.

When discussing a student's identity development based on their social class experiences, it can be inferred that although dual credit programs may provide a means of higher education access to low-income families, it can also create a more profound gap and/or barrier in the college credit earning portion of the dual credit experience (Garriott, 2019; Padgett et al., 2010; Rubin et al., 2019). As Patton et al. (2016) explains, education is responsible for creating hierarchies that reward high social class students and families while subjugating students and families from low social class backgrounds; reproducing more education inequality. Depending on the funding availability for the dual credit program provided, low social class students may have access to the dual credit course but may not be able to participate in the dual credit portion of the class due to not having the financial support (Veldman et al., 2019).

When this circumstance arises, high school students are able to be placed in the dual credit classroom and are held to the same standards and expected to complete the same coursework. Yet, because they could not afford the dual credit course registration and tuition fee, they will not earn the college credits for their participation (Capstick et al., 2019; Cram \& Bejar, 2019; Ecute, 2019). Thus, students' social class identity can be negatively developed by receiving this type of dual credit experience due to a possible feeling of inadequacy raised within them as they are unable to afford an already discounted college course. A dual credit student's negative social class identity development could potentially render them hopeless in ever being able to afford a normal college course tuition and registration fee. Short and Eadens (2019) confirm that funding is the most severe issue that creates a serious barrier in expanding dual credit programs to low-SES students to develop a clearer path to their academic achievement. Although providing dual credit options are great for the educational experiences of students, it may become especially discouraging to low social class students who cannot afford such an opportunity.

\section{POSITIVE LOW-SOCIAL CLASS IDENTITY DEVELOPMENT IN DUAL CREDIT STUDENTS}

Despite the many concerns in relation to the funding components of state implementation of dual credit programs, Short and Eadens' (2019) study supports evidence that participation in dual credit programs increases the likelihood of subsequent college matriculation; encouraging more positive social class identity development amongst low-social class dual credit students. Participating in dual credit programs offers students the ability to receive academic coaching; a collaborative relationship between an individual acting as academic coach and students focusing on his or her personal and professional goals (Capstick, Harrell-Williams, Cockrum, \& West, 2019). Statistics inferred by Short and Eadens (2019) exclaim that low socioeconomic and social class students who participated in dual credit programs were $30 \%$ more likely to enroll in college after high school and $16 \%$ more likely to graduate with a college degree than their non-dual credit peers; $77 \%$ of standard dual enrollment (SDE) students persisted to college compared to $61 \%$ of Achieving College Education (ACE) students. Capstick et al. (2019) confirms these statistics in stating that across higher education in general, both informal and formal mentoring efforts have proved effective in raising the rates of student retention, degree completion, and student support - especially with low social class and low socioeconomic student bodies.

Short and Eadens (2019) continue expressing the positive correlation between dual credit programs and traditionally underrepresented students stating that students who participate in dual credit programs not only show an increase in persistence rate in college, but also that they accrue more college credits than students who did not participate in a dual credit program. Even more, the study continues by detailing how research presents supporting evidence that low socioeconomic and social class students' high school dual credits correlate with higher GPAs at the end of their freshman college year (Short \& Eadens, 2019). It is also noted that An (2012) supports the notion that dual credit programs positively impact low social class students, as it not only provides students with an inexpensive way to take college 
courses and earn college credits while still in high school, but also helps prevent remediation of academic underprepared freshmen college students. Not only do interventions such as these move to close the social class and socioeconomic gaps in academic achievement, but long-term success also helps to improve equity in terms of access to postsecondary education and completion (Cram \& Bejar, 2019)

An (2012) claims that when high school students earn more college credits through dual enrollment programs, they are reaching a specific credit threshold that builds their academic momentum toward attaining a college degree (p.3). Dual credit accumulation benefits also have a more meaningful and significant impact on students with less educated parents compared to those with educated parents. An (2012) explains that this is primarily because students with educated parents are more likely to attend college and attain a degree, regardless of dual credit participation, whereas low-SES and social class students are positively impacted by having the experience of a college setting while still in high school. Thus, dual credit policies should be targeted at low-income schools, so that those students can be positively impacted, encouraged, and motivated to immerse in courses that let them explore ideas that go beyond the high school curriculum (An, 2012).

Students who intentionally opt out of the dual credit programs due to financial restraints are then placed at a more disadvantaged level in comparison to their higher social class peers. Creating an image of incompetence toward lower social class students and families, dual credit programs - if not implemented strategically as an all-inclusive educational opportunity - lead to students developing an identity of inability based on their low social class educational experiences. However, the intent of most dual credit programs is to empower low-SES students with a greater chance at success in higher education - opening opportunities for a brighter future - which is why most secondary and postsecondary education institutions discover ways to partner and provide dual credit courses at a fraction of the cost, if not free. Thus, it is becoming more of a concern to education policymakers to focus on suggesting an increase in the dual credit opportunities for a broader range of students; considering this initiative as a means of reducing the social class and socioeconomic gaps in college degree attainment (An, 2012).

\section{DUAL CREDIT EDUCATION POLICY MAKING}

Policymakers continue to suggest increasing dual credit opportunities to a wider range of students. This suggestion is intended to alleviate the SES gaps in college degree attainment since there is an ability to offer dual credit courses at free or discounted rates (An, 2012). Creating a push for more students to obtain dual credits though is also due to statistics proving that high school students who earned three or more college credits, through a dual credit program, are nine percent more likely to obtain a bachelor's degree (An, 2012). This information is valuable when examining the positive influence of dual credit courses on students as a whole. This also contributes to the body of knowledge that dual credit courses may provide low-social class students a greater chance at matriculating into a college degree program. When dual credit experiences are brought into historically disadvantaged schools, those students have a more positively developed social class identity since they are experiencing academics like their higher social class peers (An, 2013; Burns et al., 2019; Short \& Eadens, 2019; Veldman et al., 2019; Zinth \& Barnett, 2018).

Education policymakers should focus on developing statewide articulation agreements to provide assurance that students who wish to attend different universities within the state receive the college credits for all dual credit courses taken at the secondary education level. It should be noted that these policies do not exist in all states at this time, contributing to the continued inequity in access to higher education (Cram \& Bejar, 2019). The research of Zinth and Barnett (2018) suggests potential strategies in rethinking processes of dual credit programs to help reach more high school students - including those socially and fiscally disadvantaged. In their study, Zinth and Barnett (2018) highlight that the present state requirements across the nation may be unintentionally undermining the efforts being stressed to enlist more high school students in a more efficient pathway to college. As Burns et al. (2019) state, the original intent of early dual credit programs was to bridge student transition from high school to college. However, many stakeholders now turn to dual credit programs for additional reasons, such as to help offset the growing expense of college degree programs and to improve the matriculation and graduation rates of college students.

Similar to An (2012), Zinth and Barnett (2018) offer evidence that students with low grades in their high school classes, more typically found in students with lower social class backgrounds, benefit to a greater extent than students with higher grade point averages, subsequently higher social class backgrounds. The extent of benefits is a direct result from student participation in dual credit programs and courses. Also, students who participate in and successfully complete dual credit coursework may have increased self-confidence and ability. The successful participation and success in dual credit programs directly and positively impacts the college student's social class identity development (Burns et al., 2019). A solution that is primarily suggested is that educational policies should ensure that dual credit courses are 
more broadly accessible to students with varying levels of social class and previous academic achievement (An, 2012; Cram \& Bejar, 2019; Zinth \& Barnett, 2018).

\section{RECOMMENDATIONS AND IMPLICATIONS}

To better encourage a stronger and more self-assured student identity amongst low-social class dual credit students, school leaders and dual credit program administrators can begin by refining their local and institutional procedures. For instance, Garriott (2019) claims that researchers have proven that experiences such as not being able to participate in student activities due to time or cost and/or inability to afford textbooks are associated with first generation students' subjective social status, life satisfaction, and academic satisfaction. Patton et al. (2016) confirms these findings by explaining how these gaps, barriers, and overall discrepancies contribute to low social class students having feelings of exclusion and of being academically underprepared in comparison to their higher social class peers. Low social class students also often report lower subjective social status, feeling undervalued by their academic institutions, and tend to be the targets of negative comments from peers and faculty based on their low social class and inability to participate in campus activities (Garriott, 2019).

One recommendation to discourage these negative experiences, is that high school leaders and university dual credit administrators can create and arrange for more opportunities for dual credit students to participate in activities on the university campus. These trips to campus could include sporting events, theater and other art performances, lecture sit-ins, student research presentation days, or other similar experiences that allow all students to feel a sense of belonging through a shared campus experience. Garriott (2019) states that institution-sponsored student programming, that supports students both financially and socially, could decrease students' overall feelings of marginalization. Additionally, funding these social on-campus opportunities should be targeted at low-income schools, so that predominantly low-social class students can be positively impacted, encouraged, and motivated to immerse in courses that let them explore ideas that go beyond the high school curriculum (An, 2012).

Another recommendation that secondary education institutions could implement to encourage a broader spectrum of students to participate in dual credit programs, is to provide different variances of dual credit. The dual credit variances would allow students from diverse backgrounds to earn college credits while still in high school. Some dual credit program variations that Zinth and Barnett (2018) provide include: (a) differentiated experiences, (b) developmental coursework, (c) transition courses, (d) seminar or co-requisite, (e) career pathways, (f) student success or college-ready courses, (g) summer bridge programs, (h) college readiness brush-up programs, and (i) on-campus experiences. Providing these different styles of dual credit programming allows for a higher rate of participation of students with diverse backgrounds and needs. This ultimately encourages, promotes, and likely increases the probability of said students pursuing and later completing a college degree (Cram \& Bejar, 2019). Funding for these assorted dual credit programs is presumed to be applied with the same mechanisms and models that states are presently using for their already implemented, yet more limited dual credit programs (Zinth \& Barnett, 2018).

To encourage the reduction in social class and socioeconomic barriers to college access and attainment, another recommendation is that instead of focusing on student bodies that more commonly enroll at high tuition charging postsecondary institutions, dual credit policies need to concentrate on targeting low-income schools (An, 2012; Burns et al., 2019; Cram \& Bejar, 2019; Rubin et al., 2019). If education policies on dual credit programs concentrate on targeting low-income schools, they will be able to more efficiently and effectively provide college credits to lower social class and socioeconomic students. Dual credit programs are observed having a more substantial and positive impact in regard to postsecondary attainment and graduation. In other words, a nation-wide educational funding policy needs to be implemented in order to create the most equitable impact on postsecondary education access through dual credit programs (Cram \& Bajar, 2019). As higher education administrators serving dual credit departments, a more culturally-responsive funding model could be implemented to discourage the specific disparities faced by the institution's dual credit enrolled students.

An example of a successful culturally-responsive funding policy that is already installed within the state of Indiana is the waiving of dual credit tuition for students who qualify for the Free and Reduced Lunch Program. The Indiana Commission of Higher Education (2019) mandated that public dual credit college tuition must be waived by the higher education institution for dual credit approved students who qualify for the Free and/or Reduced Lunch program. However, further details include courses must be considered Priority Liberal Arts or Priority CTE and that the education institution partners must also complete an agreement form for tuition to be waived (ICHE, 2019). The dual credit tuition waiver 
eliminates a large portion of fees that enrolled students must pay to earn the college credits for the course, creating a more positive and encouraging educational opportunity for low-social class students.

Overall, the theoretical and conceptual connections of dual credit programs, on adolescents' social class and identity development as college students, has a significant impact on their postsecondary academic achievements (Patton et al., 2016; Padgett et al., 2010; Veldman et al., 2019). Inability to access and participate in dual credit programs as secondary education students were discovered as being main contributors to whether or not low social class students felt a sense of belonging on a campus with their middle to high social class peers. This led to an experiential disparity amongst the social classes. Evidence was also provided to support that the practicing of social experiences in a campus setting are key indicators of the academic achievement or failure of a low social class college student.

The United State Department of Education, as well as State-level Departments of Education, have progressively been reforming and creating education policies that encourage the implementation of dual credit programs. As a result, dual credit courses are increasingly being adopted in secondary education institutions - helping make waves in overall student academic development and preparation for higher education. In doing so, the inequitable educational opportunities of these programs are gradually becoming smaller. Research established a suggestion that all states should frame their educational policies on dual credit access to be as transparent and articulated as possible when referring to typically underprivileged school districts and students from low-social class backgrounds.

Future research could expand upon the direct impact that specific education policies have on state and local level dual credit program procedures and how such procedures influence student-identity development in dual credit students through a case study approach. Researchers could also further examine current and former dual credit student experiences at the institutional level, through a narrative approach, to assess how specific program procedures are influencing students' identity development on campus. This additional research could contribute to the larger body of research on student supports, college matriculation, and student identity development through on- and off-campus programs.

\section{REFERENCES}

An, B. P. (2013). The impact of dual enrollment on college degree attainment: Do low-SES students benefit?. Educational Evaluation and Policy Analysis, 35(1), 57-75.

Burns, K., Ellegood, W. A., Bernard Bracy, J. M., Duncan, M., \& Sweeney, D. C. (2019). Early college credit programs positively impact student success. Journal of Advanced Academics, 30(1), 27-49.

Capstick, M. K., Harrell-Williams, L. M., Cockrum, C. D., \& West, S. L. (2019). Exploring the effectiveness of academic coaching for academically at-risk college students. Innovative Higher Education, 44(3), 219-231.

Cram, B., \& Bejar, E. (2019). Achieving college readiness through a dual enrollment course. Metropolitan Universities, 30(2), 73-83.

Ecute, L. A. (2019). Bridging college-readiness disparities within historically underrepresented high school students. Capstone Projects and Master's Theses, 548.

Garriott, P. O. (2019). A critical cultural wealth model of first-generation and economically marginalized college students' academic and career development. Journal of Career Development, 0894845319826266.

Hanover Research. (2014). Strategies for improving student retention. https://www.hanoverresearch.com/media/Strategies-for-Improving-Student-Retention.pdf

Harris, P. M., \& Radunovich, H. (2019). Understanding the needs of incoming college freshmen: The parent perspective. UF Journal of Undergraduate Research, 20(3).

Indiana Commission of Higher Education (2019, Jan 4). Indiana dual credit frequently asked questions. https://cdn.transferin.net/wp-content/uploads/2019/01/DOE-CHE-Dual-Credit-FAQs-1.4.19.pdf

Karp, M. M., Bailey, T. R., Hughes, K. L., \& Fermin, B. J. (2004). State dual enrollment policies: Addressing access and quality. US Department of Education.

Manstead, A. (2018). The psychology of social class: How socioeconomic status impacts thought, feelings, and behavior. British Journal of Social Psychology, 57(2), 267-291. https://doi.org/10.1111/bjso.12251

Nelson, S., \& Waltz, S. (2017). Dual enrollment programs: Litigation and equity. Educational Policy, 1-32. http://dx.doi.org/10.1177/0895904817691845.

Padgett, R. D., Goodman, K. M., Johnson, M. P., Saichaie, K., Umbach, P. D., \& Pascarella, E. T. (2010). The impact of college student socialization, social class, and race on need for cognition. New Directions for Institutional Research, 2010(145), 99-111. 
Patton, L. D., Renn, K. A., Guido, F. M., Quaye, S. J., Evans, N. J., \& Forney, D. S. (2016). Student development in college: Theory, research, and practice (3rd ed.). San Francisco, CA: Jossey-Bas

Rubin, M., Evans, O., \& McGuffog, R. (2019). Social class differences in social integration at university: Implications for academic outcomes and mental health. In The Social Psychology of Inequality (pp. 87-102). Springer, Cham.

Short, L. V., \& Eadens, D. W. (2019). The impact of dual credit programs on college persistence and achievement by lowincome students. Advances in Global Education and Research. 174.

Veldman, J., Meeussen, L., \& van Laar, C. (2019). A social identity perspective on the social-class achievement gap: Academic and social adjustment in the transition to university. Group Processes \& Intergroup Relations, 22(3), 403418.

Zinth, J., \& Barnett, E. (2018). Rethinking dual enrollment to reach more students: promising practices. Education Commission of the States.

ALEXANDREA HORTON, EdD, is English Department Chair at Crown Point High School and Concurrent Enrollment Board Member for Purdue University Northwest. Her major research interests lie in federal and state education policy influence, policy implementation strategies, and dual credit partnerships. Email: ahorton8611@gmail.com

Manuscript submitted: January 29, 2021

Manuscript revised: March 11, 2021

Manuscript revised: May 5, 2021

Accepted for publication: May 5, 2021 